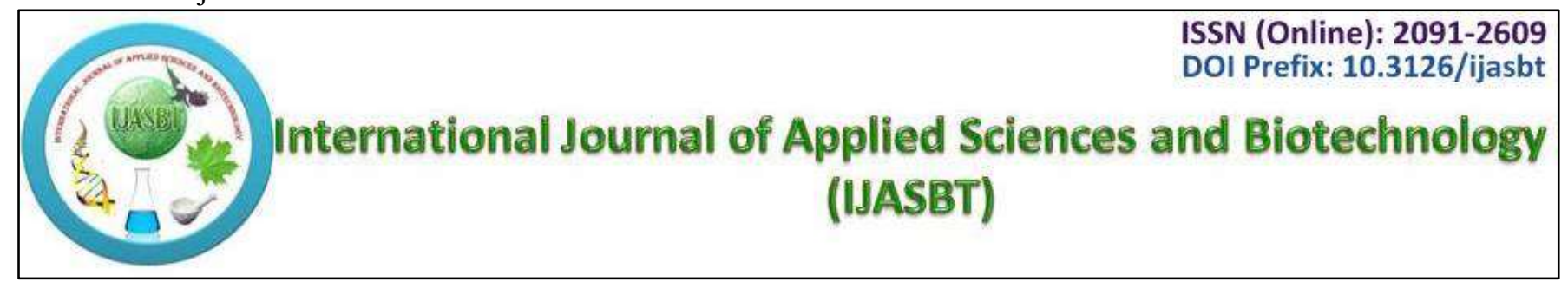

Research Article

\title{
Genomic DNA Extraction Protocol for Artemisia Anпиa L. Without Using Liquid Nitrogen and Phenol
}

\author{
A. Agrawal ${ }^{1,2 *}$, Anjana Sharma ${ }^{2}$ and N. P. Shukla ${ }^{1,3}$ \\ ${ }^{1}$ MP Council of Science and Technology, Vigyan Bhawan, Nehru Nagar, Bhopal (M.P.), India \\ ${ }^{2}$ Bacteriology laboratory, Department of Post Graduate Studies and Research in Biological Sciences, Rani Durgawati University, Jabalpur (M.P.), India \\ ${ }^{3}$ MP Pollution Control Board, E-5, Arera Colony, Bhopal (M.P.), India \\ *Corresponding author's email: ankitagr01@ gmail.com, Phone: +91 9479779972
}

\begin{abstract}
Artemisia апnиa is an important medicinal plant, used for curing various diseases especially malaria. It secretes verities of secondary metabolites which hinders in the DNA extraction. This investigation describes an efficient DNA extraction protocol for A. annua based upon the Cetyl Trimethyl Ammonium Bromide (CTAB) extraction method without using hazardous chemicals i.e. liquid nitrogen and phenol. The developed protocol is simple, reliable and operative in normal laboratory condition yielding intact DNA having good quantity (502.7 to 1288.5 $\mathrm{ng} / \mu \mathrm{l})$ and quality $\left(A_{260 / 280}\right.$ ratio - 1.82 to 1.85$)$ in two working days. Proper amplification of extracted DNA indicates its suitability for the various molecular biological applications.
\end{abstract}

Keywords: Cetyl Trimethyl Ammonium Bromide (CTAB); DNA Extraction; Artemisia annua; artemisinin; Malaria

\section{Introduction}

Artemisia апииа L. is a traditional Chinese medicinal plant well known for its bio-active compound artemisinin-an antimalarial drug. Artemisinin based Combination Therapy (ACT) is most commonly used for the curing of malaria including cerebral malaria (WHO, 2015), but low and fickle production of artemisinin does not justify the total requirement of ACT worldwide (WHO, 2011). Emphases are being made to enhance the economic commercial production of artemisinin and the molecular techniques will play a major role. Good quality, quantity and intact DNA extraction is very crucial for PCR based applications, cloning, sequencing and other molecular research. Plants which synthesize and accumulate a large numbers of bioactive compounds like A. annua (Bhakuni et al., 2001) their DNA extraction became a tedious process for the molecular biologist. Presence of polysaccharides in the extracted DNA shown to inhibit the Taq polymerase activity while the oxidized form of polyphenols covalently binds to DNA giving a brown colour and reduces maintenance time, making it useless for molecular studies (Katterman and Shattuck, 1983; Fang et al., 1992).

Although there are many DNA extraction protocol for $A$. апnиa has been developed by using liquid nitrogen and/or phenol (Kumar et al., 2011; Lakshmi et al., 2012). Sangwan et al., (1998) isolated The DNA form A. апnиa by using CTAB method that includes a rapid micro-column chromatography through DE-52 ion- exchange resin. Many researchers also used DNA extraction kits for the DNA extraction which is less time consuming and eliminate the use of toxic chemicals, however they used liquid nitrogen. But there is a need for development of DNA extraction method for normal laboratory conditions, which avoid the use of liquid nitrogen and phenols. Keeping these views, the present investigation was intent to develop a simple, efficient genomic DNA extraction protocol for A. апnиa without using liquid nitrogen and phenol.

\section{Material and Methods}

Fresh, young and disease free leaves of A. апnиa variety Jeevanraksha (Kumar et al., 1999) was taken from the medicinal plants collection of Prof. T. S. Murthy Science and Technology Station, MP Council of Science and Technology, Obaidullaganj, Raisen, Madhya Pradesh, India. Leaves were washed in a series of Millipore water, $70 \%$ ethanol and again two times in Millipore water. Fresh weight of the leaves was taken and they were chopped into fine pieces and subjected to genomic DNA isolation with following steps. 
1. The chopped leaves $(500 \mathrm{mg})$ were ground into pre-chilled mortar and pestle (at refrigerator for 1 hour) and homogenized with $700 \mu$ l of pre warmed (at $65^{\circ} \mathrm{C}$ ) extraction buffer (Haque et al., 2008) consisting, $150 \mathrm{mM}$ Tris Buffer ( $\mathrm{pH} 8.0), 25 \mathrm{mM}$ EDTA (pH 8.0), $1.5 \mathrm{M} \mathrm{NaCl}, 3.5 \%$ CTAB, 3\% PVP and $0.3 \% \beta$-mercaptoethanol.

2. The suspension was collected in $1.5 \mathrm{ml}$ Eppendorf tubes and mixed with $5 \mu \mathrm{l}$ of RNAse (stock $20 \mathrm{mg} / \mathrm{ml}$ ).

3. The Eppendorf tubes were incubated for 1 hour at $65^{\circ} \mathrm{C}$ in water bath with 2-3 times gentle inversions.

4. Equal amount of chloroform: isoamyl alcohol (24:1) was added into the room temperature (RT) cooled eppendorf tube, missed gently mixed to form a emulsion and centrifuged at $10000 \mathrm{rpm}$ for 10 minutes at RT.

5. The upper aqueous layer was taken and the step 4 (treatment of chloroform: isoamyl alcohol) was repeated again.

6. Isopropyl alcohol (0.6 volumes) was added into the upper aqueous layer, mixed well by gentle inversion and incubated at $-20{ }^{\circ} \mathrm{C}$ for 30 minutes.

7. The tubes were centrifuged at $10000 \mathrm{rpm}$ for 10 minutes at $5{ }^{0} \mathrm{C}$ and pellet was washed with $70 \%$ ethanol.

8. The pellet was air dried, dissolved in $500 \mu \mathrm{l}$ of TE buffer (10 mM Tris buffer, $\mathrm{pH} 8.0$ and 0.1mM EDTA, $\mathrm{pH}$ 8.0) and stored at $4{ }^{\circ} \mathrm{C}$ for overnight. (First day extracted DNA)

9. On the subsequent day, DNA dissolved in TE buffer was treated with equal volume of chloroform: isoamyl alcohol (24:1) added into the Eppendorf tube and centrifuged at $10000 \mathrm{rpm}$ for 10 minutes at RT.

10. Isopropyl alcohol (0.6 volumes) was added into the supernatant aqueous layer, incubated at $-20{ }^{\circ} \mathrm{C}$ for 30 minutes and centrifuged at $10000 \mathrm{rpm}$ for 10 minutes at $5^{\circ} \mathrm{C}$.

11. The pellets were washed with $70 \%$ alcohol, air dried pellet was dissolved in $50 \mu \mathrm{l}$ of TE buffer and stored at $4{ }^{\circ} \mathrm{C}$ for overnight (Second day extracted DNA).
Quantification of first and second day extracted DNA was performed in a Nanodrop spectrophotometer at $260 \mathrm{~nm}$ and the purity was checked from $A_{260} / A_{280}$ ratio. The DNA quality was also tested for PCR amplification with using EST-SSR primer (AAESP19) derived from EST sequence of A. annua. PCR reaction mixture $(20 \mu \mathrm{l})$ includes of $1 \mathrm{X}$ Red Taq PCR mix (Sigma), $1 \mu$ l of forward and reverse primers (20 pm), $1 \mu$ l of genomic DNA (25 ng) and DNAse, RNAse free water and following PCR conditions of Agrawal, (2013) i.e. $3 \mathrm{~min}$ at $94{ }^{\circ} \mathrm{C} ; 10$ cycles of $30 \mathrm{sec}$ at $94{ }^{\circ} \mathrm{C}, 30 \mathrm{sec}$ at $60{ }^{\circ} \mathrm{C}$ minus $0.5{ }^{\circ} \mathrm{C} /$ cycle, $30 \mathrm{sec}$ at $72{ }^{\circ} \mathrm{C}$; 25 cycles of $30 \mathrm{sec}$ at $94{ }^{\circ} \mathrm{C}, 30 \mathrm{sec}$ at $55^{\circ} \mathrm{C}, 45 \mathrm{sec}$ at 72 ${ }^{\circ} \mathrm{C}$; and $7 \mathrm{~min}$ at $72{ }^{\circ} \mathrm{C}$ for final extension. The PCR products were separated electrophoretically on $3 \%$ agarose gel (with $8 \mu \mathrm{l} / 100 \mathrm{ml}$ EtBr, in $1 \mathrm{X}$ TAE buffer). The EST-SSR bands on gel were visualized in gel documentation system (Alfa Inotech) under UV light.

\section{Results and Discussion}

In the present study, genomic DNA of A. annua was isolated without using liquid nitrogen and phenol in two subsequent days. The first day extracted DNA was brown in colour having DNA concentration from 742.6 to $1556.9 \mathrm{ng} / \mu 1$ with $A_{260} / A_{280}$ ratio of 0.83 to 0.95 , while the DNA concentration of second day extracted DNA was varied from $502.7 \mathrm{ng} / \mu \mathrm{l}$ to $1288.5 \mathrm{ng} / \mu \mathrm{l}$ with $A_{260} / A_{280}$ ratio of 1.82 to 1.85 (Table 1). A ratio of $A_{260} / A_{280}$ is used to assess the purity of nucleic acid. $A_{260} / A_{280}$ ratios of good quality DNA are commonly $\sim 1.8$ and ratio below this indicates the contamination of chemical constituents (Thermo Scientific). Thus the first day extracted DNA had contaminants of proteins, polysaccharides and other secondary metabolites, which was eliminated in second day by the another treatment of chloroform: isoamyl alcohol (24:1). Although The DNA concentration of first day extracted DNA was higher than second day extracted DNA, might because of residual chemical contamination present in the first day extracted DNA which result in the overestimation of DNA concentration (Thermo Scientific) or loss of DNA along with chemical contamination during the treatment of chloroform: isoamyl alcohol (24:1) on second day.

Table 1: Quantity and quality of isolated genomic DNA of A. annua

\begin{tabular}{|c|c|c|c|c|}
\hline \multirow[t]{2}{*}{ Genomic DNA } & \multicolumn{2}{|l|}{ First Day } & \multicolumn{2}{|l|}{ Second Day } \\
\hline & DNA yield $(\mathrm{ng} / \mu \mathrm{l})$ & $\mathrm{A}_{260 / 280}$ ratio & DNA yield $(\mathrm{ng} / \mu \mathrm{l})$ & $\mathrm{A}_{260 / 280}$ ratio \\
\hline AAD1 & 1556.9 & 0.95 & 1288.5 & 1.85 \\
\hline AAD2 & 824.6 & 0.87 & 528.9 & 1.84 \\
\hline AAD3 & 798.2 & 0.89 & 527.8 & 1.83 \\
\hline AAD4 & 742.6 & 0.85 & 502.7 & 1.82 \\
\hline AAD5 & 974.5 & 0.83 & 699.4 & 1.84 \\
\hline
\end{tabular}




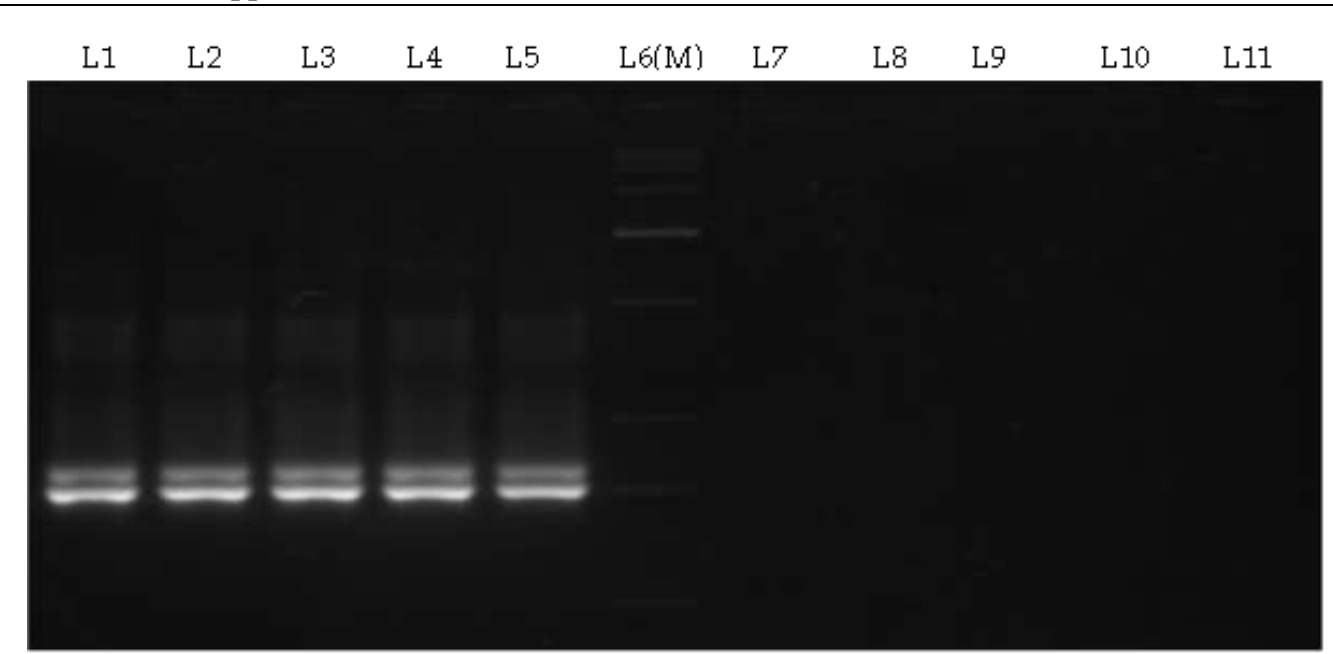

Fig.1: PCR amplification of isolated genomic DNA of A. annua by EST-SSR primer (AAESP19) in 3\% agarose gel. (AAESP - Artemisia annua EST-SSR primer). Lane 1 to 5 (L1 to L5)-Second Day extracted DNA sample AAD1 to AAD5; Lane 6 (L6M)-Low Range DNA Ruler (3000, 2500, 2000, 1500, 1000, 600, 300, 200 and 100 bp); Lane 7 to 11 (L7 to L11)-First Day extracted DNA sample AAD1 to AAD5.

Use of liquid nitrogen and phenol is very crucial in the DNA extraction procedure. Liquid nitrogen is used for grinding plant tissue to break down the cell wall of plants, while phenol used for the elimination of protein contaminants from the genomic DNA. However both the chemicals are highly hazardous in nature and thus require proper handling during the procedure, which may be not possible in the normal laboratory conditions. Therefore, efforts have been made for the isolation of genomic DNA without using these chemicals, which leads into the development of DNA extraction protocols for plants avoiding the use of liquid nitrogen and/or phenol (Sharma et al., 2003, 2010; Biswas and Biswas, 2011; Ferdous et al., 2012; Sahu et al., 2012; Sairkar el al., 2013). As for as A. annua plant, there are many DNA extraction protocols had been developed, although they use either liquid nitrogen or phenol or both (Kumar et al., 2011; Lakshmi et al., 2012). In the present investigation, genomic DNA of A. аппиа was isolated without using liquid nitrogen and phenol and yielded good quantity and quality DNA.

The extracted DNA was further checked for its proper PCR amplification through EST-SSR primer (AAESP19). The first day extracted DNA did not amplified, while the second day extracted DNA give proper amplification (Fig. 1). This confirms that the second day extracted DNA was good enough to be used for the molecular biological experiments of A. annua.

\section{Acknowledgement}

The authors are grateful to Director General, MP Council of Science and Technology, Bhopal, for providing fund as well as facility to carried out the present work, Dr. Pramod Sairkar for his valuable contribution and Dr. D. C. Jain, IPCA Laboratory, Ratlam for providing seeds of A. annua variety "Jeevanraksha".

\section{References}

Agrawal A (2013) Evaluation and Development of Simple Sequence Repeats (SSR) Molecular Marker for Artemisia annua - PhD Thesis, Rani Durgawati University, Jabalpur, India.

Bhakuni RS, Jain DC, Sharma RP and Kumar S (2001) Secondary metabolites of Artemisia annua and their biological activity. Curr. Sci. 80: 35-48.

Biswas K and Biswas R (2011) A modified method to isolate genomic DNA from plants without liquid nitrogen. Curr. Sci. 100: 1622-1624.

Fang G, Hammar S and Grumet R (1992) A quick and inexpensive method for removing polysaccharides from plant genomic DNA. BioTechniques 13: 52-56.

Ferdous J, Hanafi MM, Rafii MY and Muhammad K (2012) A quick DNA extraction protocol: Without liquid nitrogen in ambient temperature. Afr. J. Biotechnol. 11: 6956-6964.

Haque I, Bandhopadhyay R and Mukhopadyay K (2008) An optimized protocol for genomic DNA isolation from high secondary metabolites and gum containing plants. Asian J. Plant Sci. 7: 304-308. DOI: 10.3923/ajps.2008.304.308

Katterman FR and Shattuck VI (1983) An effective method of DNA isolation from the mature leaves of Gossypium species that contain large amounts of phenolic terpenoids and tannins. Prep. Biochem. 13: 347-359. DOI: 10.1080/00327488308068177

Kumar J, Mishra GP, Naik PK, Murkute AA and Srivastava RB (2011) Genomic DNA isolation from Artemisia species grown in cold desert high altitude of India. Afr. J. Biotechnol. 10: 7303-7307.

Kumar S, Banerjee S, Dwivedi S, Gupta MM, Verma RK, Jain DC, Khanuja SPS, Mathur AK, Bagchi GD, Zehra M, Mehta VK, Naqvi AA, Paul S, Ram G, Ram M, Saikia D, Sangwan RS, Kumar TRS, Shasany AK, Darokar MP, Singh AK and Singh A (1999) Registration of Jeevanraksha and Suraksha varieties of the anti-malarial 
medicinal plant Artemisia annua. J. Med. Aromat. Plant Sci. 21: 47-48.

Lakshmi N, Pingili D, Raj SM. 2012. RAPD studies on genomic DNA isolated from antimalarial plants: Eucalyptus globulus Labill. (Eucalyptus) and Artemesia annua L. (Artemesia). Annals of Phytomedicine 1(1): 90-94.

Sahu SK, Thangaraj M and Kathiresan K (2012) DNA Extraction Protocol for Plants with High Levels of Secondary Metabolites and Polysaccharides without Using Liquid Nitrogen and Phenol. ISRN Mol. Biol. DOI: $10.5402 / 2012 / 205049$

Sairkar P, Chouhan S, Batav N and Sharma R (2013) Optimization of DNA isolation process and enhancement of RAPD PCR for low quality genomic DNA of Terminalia arjuna. $J$. Genet. Eng. Biotechnol. 11(1): 17-24. DOI: 10.1016/j.jgeb.2013.02.001

Sangwan, NS, Sangwan RS Kumar S. 1998. Isolation of Genomic DNA from the Antimalarial Plant Artemisia annua. Plant
Mol. Biol. Rep. 16(4): 365-365. DOI: 10.1023/A:1007545102889

Sharma P, Joshi N and Sharma A (2010) Isolation of genomic DNA from medicinal plants without liquid nitrogen. Indian J. Exp. Biol. 48(6): 610-614

Sharma R, Mahla HR, Mohapatra T, Bhargava SC and Sharma MM (2003) Isolating plant genomic DNA without liquid nitrogen. Plant Mol. Biol. Rep. 21: 43-50. DOI: 10.1007/BF02773395

Thermo Scientific. T042-Technical Bulletin NanoDrop Spectrophotometers.

http://www.nanodrop.com/Library/T042-NanoDropSpectrophotometers-Nucleic-Acid-Purity-Ratios.pdf

WHO (2011) World Malaria Report 2011. World Health Organization, Geneva.

WHO (2015) Guidelines for the treatment of malaria, Third edition. World Health Organization, Genava. 